\title{
Research on Xi Jinping's Important Exposition on Information Technology Education
}

\author{
He Hua ${ }^{1, *}$ \\ ${ }^{1}$ Marxist collegeMianyang Mianyang Normal University, Mianyang, Sichuan, China
}

\begin{abstract}
Since the 18th National Congress of the Communist Party of China, Xi Jinping has made important instructions and discussions on information technology education on many occasions, and formed a systematic thoughts on information technology education. Xi Jinping's exposition on information technology education includes information technology education must adhere to marxism as a guide,pay more attention to the education of children and adolescents, adhere to the fundamental direction of khalid ents, enhance the level of teachers' modern education and deepening the reform of modern information technology education, quicken the development of vocational education,create a good classroom teaching with modern information technology, uphold the Party's overall leadership over information technology and education,create a new landscape of cyber security, and build a community of shared future in cyberspace. This paper adopts the method of literature research, through studing a series of important expositions of Xi Jinping on information technology education, it can not only provide important reference for the reform and innovation of information technology education, but also provide important guidance for the correct direction of information technology education.
\end{abstract}

\section{Introduction}

Since the beginning of this century, with the in-depth development of global economic integration, the rapid development of information technology and Internet technology, the whole world has continuously entered the era of knowledge economy. The industrialization task of our country has not been completed, and ushered in the tide of information age. Therefore, the CPC Central Committee has repeatedly stressed that we should not only complete the unfinished task of industrialization, but also seize the trend of the information age, integrate industrialization and informatization, and take a new road of industrialization with Chinese characteristics so as to catch up with the advanced developed countries in the world. This needs to train the shoulder to master the information technology of The Times. School is an important position for training young students to master information technology. How to enhance students' awareness of information technology and enhance the level of information technology in school education is not only related to the future of the country and the rejuvenation of the nation, but also related to the growth and development of the future generation. Therefore, since the 18th National Congress of the Communist Party of China, Xi Jinping has made important instructions and discussions on information technology education on many occasions, and formed a systematic thought on information technology education. By studying a series of $\mathrm{Xi}$ Jinping's thoughts on information technology education, this paper hopes to point out the direction for the development of socialist education with Chinese characteristics and provide talent support and ideological impetus for the national rejuvenation.

\section{Adhere to Marxism as Our Guide}

To do a good job in information technology education, we must adhere to the scientific guiding ideology and correct political orientation.Marxism is not only the guiding ideology of our party and country, but also the guiding ideology of our information technology educational work.All kinds of schools at all levels in our country are schools under the leadership of the party, are schools to train socialist builders and successors, colleges and universities, especially in China"will be to consolidate marxist guiding status and development of the important places for socialist ideology"[1], to be a main position of marxism theory education, for students' life to lay the ideological foundation of science. The school should shoulder the responsibility of cultivating and carrying forward the core socialist values, and guide the teachers and students to be firm believers, active disseminators and exemplary practitioners of the core socialist values. Only by adhering to the guidance of Marxism, unremittingly spreading Marxist scientific theory, cultivating and carrying forward socialist core values, promoting harmony and stability of the school, and cultivating fine school spirit and study spirit, can we guide the school to correct the direction of running the 
school,build a solid ideological foundation, provide value guidance, and train a large number of qualified talents.

\section{Pay Attention to the Study of Traditional Culture}

The essence and the true meaning of education is to cultivate people with culture. Xi pointed out that while vigorously promoting information technology, we should vigorously promote the development of cultural undertakings.Through cultural exchanges, hearts and minds can be connected, horizons can be broadened,consensus can be enhanced, people can improve their quality among the continuous literate people, and culture can contribute to human progress. He stressed the need to strengthen the study and inheritance of traditional Chinese culture, and proposed that the cultivation and promotion of socialist core values must be based on the excellent traditional Chinese culture. Xi stressed the need to carry on the tradition and carry out creative transformation and innovative development. "To abandon tradition and root is to cut off one's spiritual lifeline," ${ }^{[2]} \mathrm{Xi}$ said.

When visiting Beijing Normal University, Xi Jinping pointed out the phenomenon of "desinification" : "I don't want to remove the ancient classics of poetry and prose from the textbooks and add a lot of Western things.I think 'desinification' is very sad. These classics should be embedded in the minds of students and become the cultural genes of the Chinese nation. ${ }^{[[3]} \mathrm{He}$ not only stressed the importance of learning traditional Chinese culture, but also put forward the methods of learning, that is, adhere to the past for the present,bring forth the new, treat it discriminatively, and inherit it where sublated, and strive to use all the spiritual wealth created by the Chinese nation to educate people with culture. Traditional culture is the root and sources of our spiritual development. If we lose it, we will lose our spiritual home and value.Of course, to the traditional culture, we should take a dialectical perspective of development to look at it, to carry on the transformation of the times, give it a new content of the times.

\section{Pay Attention to the Education of Children and Adolescents}

Children are the future and hope of our countryare,and the pillar of the future information technology. The whole society should understand,respect,care for and serve children and provide a good social environment for them, Xi said. Words and deeds that harm the rights and interests of children and damage their physical and mental health must be resolutely prevented and punished in accordance with the law.During his visit to Beijing Normal University,he proposed that we should pay special attention to the education of special children,such as children with autism, AIDS, etc., and help them grow up with love and scientific methods. He paid close attention to children in the western region, rural areas, old revolutionary base areas,minority areas, border areas and poor areas, and called for greater support to solve problems such as shortcomings in education and fairness in education.

He has great hopes for young people, too. Because young people are the main talents of the future information technology. In the Beijing Normal University, he asks the youth to study and strive for virtues, discernment, probity,have to effort,get true knowledge,strengthen moral accomplishment, pay attention to moral practice,be good at distinguish between right and wrong, good at making decisions and choices, solidly work, be a down-to-earth person, be determined to serve country and people, exert oneself to do STH , work hard from the unity of knowledge and action.He urged them to "buckle the buttons of life from the very beginning,"and urged young people to start from now on and on their own, consciously cultivate and practice core socialist values, and make them the basic principles of their thinking and actions.

\section{Adhere to the Fundamental Direction of Moral Education}

Moral education is the essence and the true meaning of school education. Therefore, Xi Jinping emphasized that moral education should be integrated into all aspects of ideological and moral education, cultural and knowledge education, and social practice education, which should run through all fields of basic education,vocational education, and higher education. School education should not only pass on knowledge, cultivate high-end talents who master modern information technology, but also aim to cultivate people with moral integrity. Besides meeting development needs of the young people, school education should also meet expectations of the society and the country. The core mission of teachers is to cultivate people by virtue. The quality of students includes scientific and cultural quality and ideological,political and moral quality. We should not only enhance students' scientific and cultural knowledge, but also strengthen students' ideological, political and moral education, and help students to establish a correct outlook on the world, life and values. The goal of education is to cultivate people by virtue, which is the essence and core idea of education, while ideological, political and moral education focuses on training students how to behave and become talents, which is the most important factor for students' growth If a student's thoughts and morals go wrong, even if he is well educated, he will do harm to the society.

The lessons of Ma Jiajue, Yao Jiaxin, Lin Senhao and many others who have gone down the wrong path tell us that IQ, knowledge, scores and rankings are secondary, while ideological and moral education is the main thing. National juvenile delinquency rate in 2012: Approximately $18 \%$, gang crime rate $85 \%$, 14 - to 16-year-olds rate $80 \%$.According to statistics, the use of Internet crime by teenagers is also increasing. Due to the utilitarian tendency of education in some places, teachers emphasize too much on students' learning and education of scientific and cultural knowledge, but neglect the 
ideological and moral education of students, which leads to problems in students' moral character.Students' ideological and moral education is delayed, and the spiritual world becomes hollow, desertification and evil, so that rationality is lost, and bad roots are planted.It is also natural to do harm to society. This is not only a dereliction of duty of school and social education,but also a dereliction of duty of family education. The most important education is to get rid of utilitarian education, let the children stick to their spiritual home, and cultivate them to be caring, responsible, honest and kind.

Therefore, Xi Jinping emphasized that ideological, political and moral education should be strengthened for young students, especially in colleges and universities, and students' ideological guidance should be attached importance to firmly grasp the leadership of ideological work in colleges and universities. He urged the propaganda and ideological departments to shoulder their due responsibilities and carry out in-depth ideological education of socialism with Chinese characteristics, so as to unite and condensed the people of all ethnic groups in realizing the goal of the great rejuvenation of the Chinese nation.

\section{Strengthen the Ranks of Teachers}

The century-old plan is based on education. Teachers are the foundation of teaching and the source of teaching. Good education cannot be achieved without good teachers.As Xi pointed out,"Only the kind of teachers can produce the kind of students, and teacher training is related to the whole education."We should cultivate and bring up a team of high-quality professional teachers who have ideals and beliefs, moral sentiments, solid knowledge and benevolence." Four teachers"are the four standards of a good teacher.

Have ideals and beliefs.Learn to be a teacher, behavior world fan.Good teachers should firmly uphold the ideals and beliefs of socialism with Chinese characteristics, be active communicators of the common ideal of socialism with Chinese characteristics and the Chinese dream of great national renewal, help students to seek, build,pursue and fulfill their dreams, and enable generation after generation of young people to become positive energy in realizing the dream of our nation.

Be moral. A teacher's influence on his students cannot be separated from his own knowledge and ability, but also from the values he holds in the way he conducts himself,the country, the people, the public and the private. The teacher's first responsibility is "preaching", through constantly improve their own moral cultivation, personality quality, impart the correct moral concept to students,guide and help students grasp the direction of life, "buckle the first button of life".

Must have solid knowledge. Solid knowledge foundation, excellent teaching ability, diligent teaching attitude and scientific teaching methods, mastering modern science and information technology are the basic qualities of a teacher, among which professionalknowledge is the fundamental foundation. A good teacher should also be an intelligent teacher, who has the wisdom of learning, dealing with the world, living and educating people. He can teach students according to their aptitude and can help and guide them in all aspects.

Have a heart of love. Love is the soul and true meaning of education, education without love is a failure of education. Teachers must be engaged in the education of love.Cultivate love with love, inspire love, transfer love, with true feelings, sincerity, sincere impress students, nourish the hearts of students. Affect students with their own warmth and emotion, enhance students' confidence with appreciation, establish students' self-esteem with trust, so that every student can grow up healthily and happily.

In addition, $\mathrm{Xi}$ urged Party committees and governments at all levels to care about teachers, improve their quality, improve their benefits, care about their health and safeguard their rights and interests. The whole society should vigorously promote the good custom of respecting teachers and valuing education, and make teachers the most respected profession in society.

\section{Continue to Deepen Education Reform and Innovation}

Reform and innovation are the fundamental driving force for the success of the cause of socialism with Chinese characteristics,as well as for strengthening and improving school education. Educational reform and innovation play an important role in promoting education.Xi Jinping therefore stressed the need to deepen education reform and innovation,promote quality-oriented education, innovate education methods,improve the quality of talent training, and strive to form an educational environment conducive to the growth of innovative talents.School is not only to enable students to master specific knowledge,but also to exercise students' thinking and improve their ability. Schools should actively change the way of thinking, through the reform and innovation of teaching content and teaching methods and techniques, so as to make the traditional dead teaching "alive" and "moving", so as to infect and influence the students.Colleges and universities should persist in reform and innovation,speed up the establishment of a discipline system, textbook system and discourse system for philosophy and social sciences with Chinese characteristics, pay more attention to educating people with culture and literature, use new media and new technologies, and constantly promote innovation in ideas and methods of ideological and political work, so as to invigorate ideological and political work.

$\mathrm{Xi}$ urged teachers to actively contribute to Chinese education reform and innovation. The building of a modernized socialist education system with Chinese characteristics is a great practice that has never been done before, and it is impossible to copy foreign countries. It depends on the efforts of the Chinese people, especially teachers. No matter how good the top-level design of national education is, it cannot be realized without the full recognition, active participation and independent innovation of the majority of teachers.All 
the achievements of education and teaching reform that win the hearts of the people are permeated with the efforts of teachers who are brave and innovative.

Educational reform and innovation is a systematic project, and cannot be eager for quick success and instant benefits. As the saying goes, it takes ten years to grow trees, but a hundred to grow people.Special attention should be paid to equity in education.In response,Xi called for greater input to ensure that the 1.4 billion people enjoy better and fairer education and have the ability to develop themselves, contribute to society and benefit the people.

\section{Accelerate the Development of Vocational Education}

What kind of people to train,how to train people, this is the starting point and foothold of all educational work.With the transformation of the mode of economic development, the adjustment of industrial structure and the acceleration of technological innovation, and the adaptation to the new normal of Chinese economic development, education should provide a large number of high-quality workers and technical and skilled personnel that meet the requirements. This needs to play the role of vocational education.As $\mathrm{Xi}$ Jinping pointed out,vocational education is an important part of the national education system and human resources development, and it is an important way for young people to open the door to success.It shoulders the important responsibilities of cultivating diversified talents,passing on technical skills, and promoting employment and entrepreneurship. Therefore, it must be attached great importance to and expedites its development.

We should take cultivating morality and educating people as our fundamental task, stick to the direction of applying technology in running schools, set up majors to meet the needs of the society, lay a good foundation, and train socialist builders and successors who are well developed morally, intellectually, physically, aesthetically, and with hard work.We Must firmly grasp the school-running orientation of service development, promoting employment,we will deepen reform of the system and mechanism and innovation at all levels all kinds of vocational education mode, adhere to the fusion, between production and education cooperation, adhere to the combination and unity, guide enterprises to actively support the social from all walks of life especially industry vocational education,strive to build a vocational education system with Chinese characteristics. We need to increase support for vocational education in rural areas,ethnic minority areas, and poor areas,so that everyone has the chance to excel in life.He pointed out that education should be combined with local economic and social development,and education should contribute to local economic and social undertakings. He urged Party committees and governments at all levels to give greater prominence to accelerating the development of modern vocational education, better support and help the development of vocational education, and provide a solid talent guarantee for the realization of the "two centenary goals" and the Chinese dream of national rejuvenation.

\section{Adhere to Based on China}

General Secretary Xi Jinping once put forward the "shoe theory", that is, "you can only know whether a shoe fits your foot until you wear it". He pointed out that only the people of a country have the best say on whether the development path of the country is suitable or not.He pointed out that "the great social change in contemporary China is not a simple continuation of our history and culture, is not a simple copy of the template of classical Marxist writers, is not a reprint of other countries' socialist practice, and is not a copy of foreign modernization development, it is impossible to find ready-made textbooks." ${ }^{[4]}$ This determines the unique path of the development of Chinese contemporary higher education, and also determines the uniqueness of the ideological and political work in our current colleges and universities. We should not take the old path of the development of the ideological and political work in Chinese colleges and universities, nor the path of the ideological and political work in other countries, but should take the path of the ideological and political work in the socialist colleges and universities with Chinese characteristics. Chinese unique history, culture and national conditions determine that China must follow its own path of developing education with Chinese characteristics and run socialist colleges and universities with Chinese characteristics well. Where does the confidence and root to run education in China come from? It comes from Chinese"rich historical and cultural accumulation,rich practice in reform, opening up and socialist modernization, and growing confidence in the path, theory, system and culture". On the basis of inheriting the fine traditional Chinese educational thinking and effective methods, we should combine the curriculum,practice, experience and value pursuit of socialism with Chinese characteristics, so that the development direction of education is in line with the development direction of the country. We should not only take root in China, but also have an international mind.We should not only base ourselves on The Times,but also face the future, so as to find the way of running schools in accordance with the law of the development of modern Chinese education.We will comprehensively deepen education reform and innovation, and work toward the goal of developing modern education with Chinese characteristics and on a world level. He stressed the need to "draw on advanced international experience and promote education reform" ${ }^{[5]}$. Foreign advanced experience and teaching methods in running schools should be carefully used for reference and absorbed, and should not be "brought doctrine", and should be creatively transformed and developed. 


\section{Meet the Needs of The Times}

Education should be geared to modernization,the world and the future, and should not follow the path of self-closed development.Correct understanding of Chinese characteristics and international comparison, objective understanding of the differences between Chinese and Western culture. Educators should have a world vision and global vision, enhance the sense of The Times and the cutting-edge of education and teaching, expand the international vision of education and teaching, and enhance the vitality of innovation. Education should change according to the situation, progress according to The Times, and change according to the situation. Comprehensive and objective understanding of contemporary China,must stand in front row, the world's advanced development and international comparison, the correct view of the outside world, the correct understanding time responsibility and historical mission, using international advanced new media technologies,promote education work with highly integration of modern information technology, traditional advantage continue to increase the pertinence and effectiveness of education.Party committees and departments of publicity and ideology,organization and education at all levels should adhere to the Party's educational policy the socialist orientation for running schools, methods for strengthening and improving educational work,and earnestly implement the Party's responsibility to supervise the Party and to govern the Party strictly in school education.

\section{Make Good Classroom Teaching with Modern Information Technology}

Theory courses in colleges and universities are not only courses for students to master specific knowledge, but also courses to train students' innovative thinking and enhance their ability to master modern technology and thinking methods.Colleges and universities should seriously pay attention to the education of Marxist theory to lay a scientific ideological foundation for the growth of students. At the same time, Colleges and universities should let the students master the modern information technology.Teachers should not only have a deep theory and absorb the extensive knowledge accumulated by human beings, Master modern educational technology means,but also have the passion and enthusiasm to care about the social reality and take the interests of the people as the center.On the one hand, teachers in colleges and universities should delve deeply into theories so as to convince and convince people.At the same time, they should be sensitive to practical problems to trigger theoretical thinking and combine the depth and temperature of education. Therefore, colleges and universities should continue to strengthen the theory literacy teachers, to expand the depth of theory research, organize teachers to deeply read the classic works on the basis of enhancing the penetration of theory courses. On the other hand, teachers should be passionate and warm in class to enhance the appeal and attraction of theory, should make education more attractive through innovation and improvement of educational means. They should persist in improving and constantly enhance the affinity and pertinence of education, so as to meet the needs and expectations of students for growth and success. The teachers in colleges and universities should broaden their vision,improve their professional ability, reform their teaching methods, innovate their educational models, deeply cultivate their teaching materials, and improve the teaching quality of theory courses.

\section{Uphold the Party's Overall Leadership over Higher Education}

Information technology education is inseparable from the guidance of the Party.As Xi Jinping pointed out, " The most essential feature of socialism with Chinese characteristics is the leadership of the Communist Party of China."[6] As an important part of the cause of socialism with Chinese characteristics, Chinese higher education should naturally accept the leadership of the Party, adhere to the leadership of the Party,and firmly grasp the leadership of the Party in the work of colleges and universities. The Party should strengthen leadership in education at all levels and in all types of schools, especially in colleges and universities.Because universities shoulder the important task of studying, researching and propagating Marxism and training builders and successors of the cause of socialism with Chinese characteristics. Therefore, it is of vital importance to do a good job of the Party's overall leadership over colleges and universities and to plan the overall situation of college education. To strengthen the Party's leadership over colleges and universities is to adhere to and improve the system of president responsibility under the leadership of the Party committee, and constantly reform and improve the institutions and mechanisms of colleges and universities.

It is necessary to comprehensively enhance the political consciousness, responsibility consciousness and position consciousness of college teachers, firmly grasp the leadership and dominance of the ideological work in colleges and universities,persist in guiding public opinion with the theory of socialism with Chinese characteristics, rally people together with the core socialist values, and consolidate the guiding position of Marxism in the field of ideology in colleges and universities.We should improve the ideological responsibility system for Party committees in colleges and universities,and improve classroom teaching,reports, seminars,lectures,forums and network management.Leading Party cadres in colleges and universities at all levels should give full play to the role of Party organizations as battle forts and the vanguard and exemplary role of Party members,and consciously practice modern educational concepts,master online public opinion and information security.

In today's China,there is no political force that can compete with the political power of the Communist Party of China,and the leadership of the Party must be firmly and consciously upheld in every field and aspect of our country.Party committees in colleges and universities 
should exercise overall leadership over the work of their institutions, assume the main responsibility of governing the Party and running schools, ensure that colleges and universities are in the right direction of running schools, grasp the dominant power of ideological and political work in colleges and universities, and ensure that colleges and universities are always the main front for training builders and successors of the socialist cause.Party secretaries of all localities and Party secretaries of relevant departments should make more visits to colleges and universities, have more contact with teachers and students, give more reports to colleges and universities, pay close attention to the development of colleges and universities, and answer theoretical and practical issues of common concern to teachers and students.

\section{Foster a New Cyber Security Landscape and Build a Community of Shared Future in Cyberspace}

In today's world, a new round of scientific and industrial revolution is underway, driving the rapid development of digital technology. In the network information age, Xi Jinping put forward that we should grasp the network information and security, grasp the online public opinion, grasp the online ideological position. Especially since COVID - 19 outbreak, telemedicine, online education, sharing platform, collaborative office is widely used, such as the Internet is not only to promote world economic recovery, safeguard social operation, played an important role to foster international cooperation on resistance to disease, but also to the informationization, digital education provides an important opportunity, had an important effect. We should seize the historic opportunity of the information revolution, foster new drivers of innovation and development, open up new prospects for digital cooperation, foster a new landscape of cyber security, build a community of shared future in cyberspace, and work together to create a better future for mankind.

\section{CONCLUSION}

To sum up, $\mathrm{Xi}$ Jinping's discussion on information technology education is comprehensive, rich and profound, and full of ardent expectations and confidence for the development prospects of China's information technology and digital economy. This is not only of great guiding significance to the development of China's information technology education, but also plays an important role in how the young generation of China meets the tide of The Times, constantly innovates and develops, and meets the needs of the motherland and The Times.

\section{Acknowledgments}

This paper is one of the phased results of the project funded by the introduction of talents by Mianyang Normal University (subject No. : QD2012B06).

\section{References}

1. "Consolidate Marxism Important Positions". http://theory.people.com.cn/n/2013/1011/c405 31-23162141.html, 2013-10-11.

2. Publicity Department of the CPC Central Committee,Readings of General Secretary Xi Jinping Series of Important Speeches, People's Publishing House, pp. 2014.

3. It is not appropriate to "de-sinicize", but to "retain the roots".

http://cpc.people.com.cn/pinglun/n/2014/0911/c2412 20-25644423.html, 2014-9-11.

4. Written by Xi Jinping: The Governance of China, Foreign Languages Publishing Society, vol.3, pp.76,2020.

5. Powerful ideological weapon to promote reform and development of education Learn from General Secretary $\mathrm{Xi}$ Jinping's important exposition on education.

http://news.12371.cn/2014/04/16/ARTI13976100869 33459.shtml?from=singlemessage, In the 2014-4-16.

6. Written by Xi Jinping, Xi Jinping: The Governance of China, Foreign Languages Publishing Society, vol.2, pp.18,2017. 